UDK 582.632.1:581.45(497.6)

\title{
MORPHOLOGICAL IDENTIFICATION OF NOTHOSPECIES ALNUS $X$ PUBESCENS TAUSCH. AND THEIR NEW LOCALITIES IN CENTRAL BOSNIA
}

\author{
Morfološka identifikacija nothovrste Alnus $X$ pubescens Tausch. i njena \\ nova nalazišta u Centralnoj Bosni
}

Neđad Bašić ${ }^{1}$, Eldin Selimović ${ }^{2}$, Fatima Pustahija ${ }^{1}$

\begin{abstract}
Natural interspecies hybrids of black (Alnus glutinosa (L.) Gaertn) and grey (A. incana (L.) Moench) alder are not frequent in nature but they are registered, and according to modern systematic nomenclature are classified within nothospecies $A$. $\times$ pubescens Tausch.. Since the presence of spontaneous intermediate forms of the genus Alnus in Bosnia and Herzegovina is insufficiently explored, the first results of comparative morphological analysis (seven leaf's characters) of black and grey alder and their hybrids are given in this study. About $10 \%$ of hybrid individuals were present in the studied sympatric populations, and they had more heterogeneous leaves than parental species. Good diagnostic characters showed intermediate values in comparison to the parental species, which are: number of pairs of lateral veins, angle from the top of the leaflet to the top of the upper $3^{\text {rd }}$ nerve, and distance from the top of the leaflet to the top of the upper $3^{\text {rd }}$ vein. According to analyzed characters, hybrids either hold intermediate positions between the parental species or are closer to the maternal species (A. incana). Three new findings of nothospecies $A . \times$ pubescens for Flora $B \& H$ are rivers' localities Drinjača near Kladanj, Turbe near Travnik, and Stavnja near Vareš. Due to the low frequency of observed individuals of $A$. x pubescens, they are vulnerable and require special measures of protection and biodiversity conservation activities of autochthonous gene pool, it is necessary to determine the actual state in all previously published hybrid complexes' findings and expand researches in $\mathrm{B} \& \mathrm{H}$ in the coming period.
\end{abstract}

Key words: alder, morphometry, natural hybridization, sympatry, variation

\footnotetext{
${ }^{1}$ Faculty of Forestry, University of Sarajevo

${ }^{2}$ Institute for forestry and horticulture
} 


\section{INTRODUCTION - Uvod}

The genus Alnus Mill. contains 20-35 deciduous trees and shrubs, predominantly distributed in the northern Hemisphere, with the exception of one South American species (Hall and Burgess 1990, Vanden Heuvel 2011). Leaf morphology variation shows continuity both within and between species, making distinction between the species very difficult. The genus belongs to the family Betulaceae, and morphologically clearly differentiated from its closest relatives of the genus Betula L.. On the Balkan Peninsula alders are presented with three autochthonous [A. glutinosa (L.) Gaertn, A. incana (L.) Moench, A. viridis (Chaix) DC)] and one hybrid species (A. $\times$ pubescens Tausch.). In addition to these species, in Europe is naturally present and $A$. cordata Desf. in Corsica and South-East of Italy (BALL 1964). Species of the genus are clearly differentiated in three subgenera: Alnus, Alnobetula i Clethropsis, with seven major distribution centers in the world (FURLOW 1979, BanaeV and BažAnt 2007, VANDEN Heuvel 2011).

In the Flora of Bosnia and Herzegovina are registered black (A. glutinosa), grey (A. incana) i green alder (A. viridis), and two hybrid species betwen black and grey alder marked as $A . \times$ tauschiana Callier and A. × ambigua G. Beck (BECK 1907). These two hybrid taxa are stored in the herbarium of the National Museum of Bosnia and Herzegovina in Sarajevo (SARA). However, a hybrid complex of black and grey alder, according to modern systematic nomenclature observations, now is classified within nothospecies $A$. × pubescens (FUKAREK 1959, BALL 1964, BANAEV AND BAŽANT 2007, Vanden Heuvel 2011, The Plant List 2013).

The presence of intermediate forms of the genus Alnus in Bosnia and Herzegovina is insufficiently explored and as such falls within the unresolved morphodendrological and dendrogeographical questions, as pointed FUKAREK (1962). Natural alder's interspecies hybrids are not frequent, but they are registered and studied in Europe (Belarus, Czech Republic, Ireland, Latvia, Montenegro, Poland, Serbia and Sweden), the Russian Far East, North America, and Japan. To today, documented hybrids are A glutinosa $\times$ A. incana (HYLANDER 1957, VUKIĆEVIĆ AND JoVANOVIĆ 1983, PARNELl 1994, BANAEV AND BAŽANT 2007), A. serrulata $\times$ A. rugosa (STEEle 1961, Furlow 1979), A. sinuate $\times$ A. crispa (Bousguet et Al. 1989, 1990), and A. glutinosa $\times$ A. rubra (HALL AND BURGESS 1990).

Natural hybrids of black and grey alder possess many economically important characteristics: they have a greater resistance to drought compared to the parental species, heterosis, less demand for fertility, have a higher quality wood and more resistance to certain forms of rot. Because of this, interspecies hybridization within the genus may be an important strategy for improving the species, and hybrids can be interesting as resources for the selection (BANAEV AND BAŽANT 2007, VANDEN HEUVEL 2011 and references therein).

Sympatric populations of black and grey alder are of particular interest as potential areas of natural and spontaneous hybridization to form hybrid complexes that contribute to higher levels of biological and morphological diversity within this genus. 
In order to more comprehensive consideration of inter- and intraspecies relationships between black and grey alder we approached morphological and taxonomic determinations. The results of these studies should provide the lack information about the presence and characteristics of their hybrid complex in the southeast of the ranges, which has not been done till today.

\section{MATERIAL AND METHODS - Materijal i metode istraivanja}

Collection of leaf material was carried out in six environmentally heterogeneous sympatric populations (Figure 1, Table 1). Per five leaves from fruiting branches (in total of 55 individuals) were morphometrically analyzed. According to modified method of BANAEV AND BAŽANT (2007), variability of seven morphological leaf's characters were analyzed: length of a leaf blade, width of a leaf blade, distance from the base of a leaf blade to its widest part, length of a leafstalk, distance from the top of the leaflet to the top of the upper $3^{\text {rd }}$ vein, angle from the top of the leaflet to the top of the upper $3^{\text {rd }}$ nerve, and number of pairs of lateral veins (Figure 2). The separation of hybrid individuals, in relation to the parent species, was done by comparative morphological methods and consultation of various reference sources.

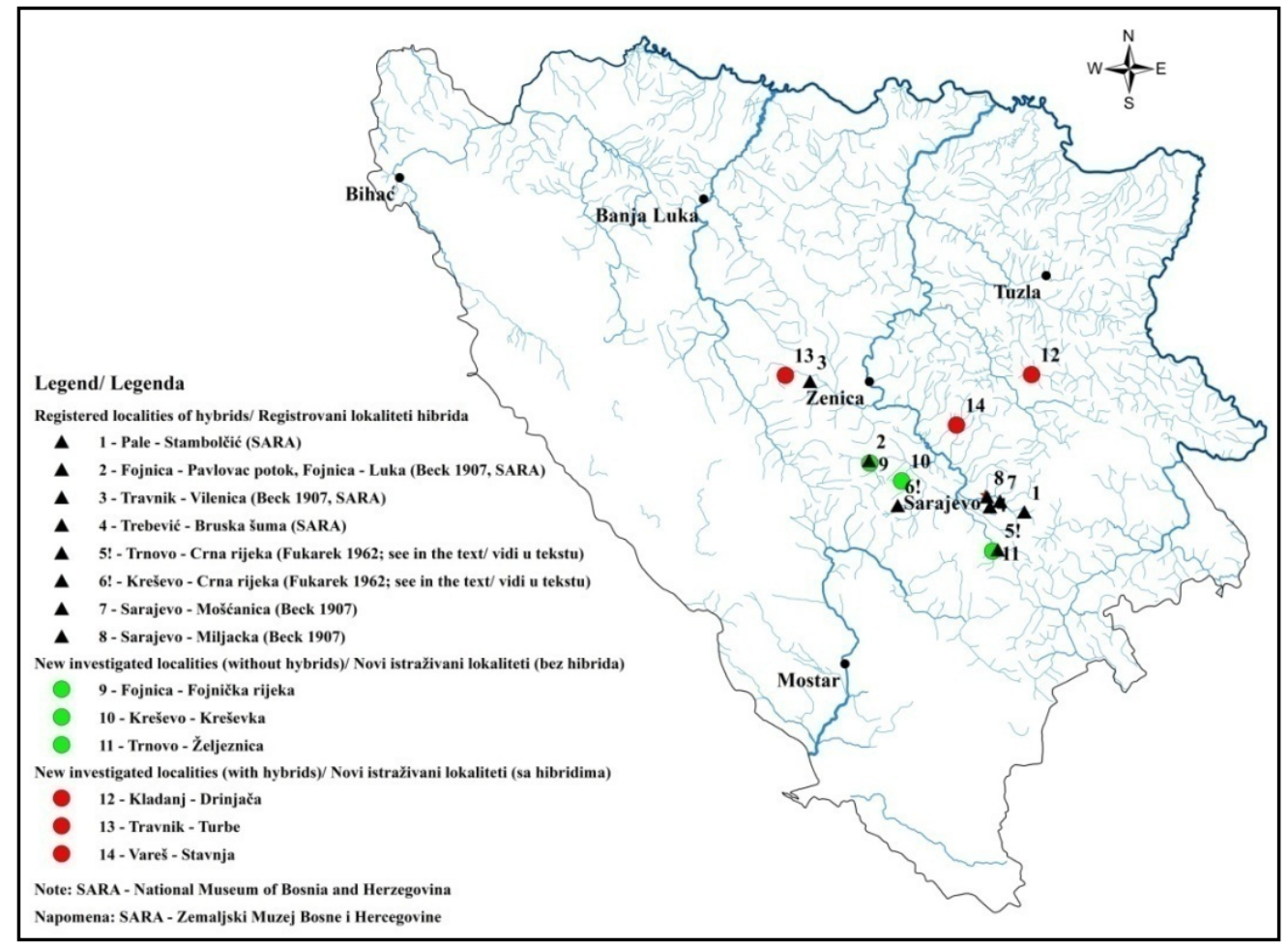

Figure 1. Registered and investigated localities of $A$. x pubescens in $\mathrm{B} \& \mathrm{H}$

Slika 1. Registrovani i istraživani lokaliteti A. $x$ pubescens $u B \& H$ 
Table 1. Investigated populations of alders

Tabela 1. Istraživane populacije joha

\begin{tabular}{|c|c|c|c|}
\hline Locality/ Lokalitet & $\begin{array}{c}\text { Number of } \\
\text { analyzed } \\
\text { individuals/ Broj } \\
\text { analiziranih jedinki }\end{array}$ & $\begin{array}{l}\text { Geological substrate/ } \\
\text { Geološka podloga }\end{array}$ & $\begin{array}{c}\text { Altitude (m)/ } \\
\text { Nadmorska visina } \\
\text { (m) }\end{array}$ \\
\hline Kladanj - Drinjača & 10 & $\begin{array}{l}\text { Peridotite - serpentine/ } \\
\text { Peridotit - serpentin }\end{array}$ & $670-740$ \\
\hline Travnik - Turbe & 5 & Limestone/ Krečnjak & $621-626$ \\
\hline Vareš - Stavnja & 10 & Silicate/ Silikati & $575-629$ \\
\hline Fojnica - Fojnička rijeka & 10 & Silicate/ Silikati & $560-620$ \\
\hline Kreševo - Kreševka & 10 & Silicate/ Silikati & $535-546$ \\
\hline Trnovo - Željeznica & 10 & Limestone/ Krečnjak & $790-819$ \\
\hline
\end{tabular}

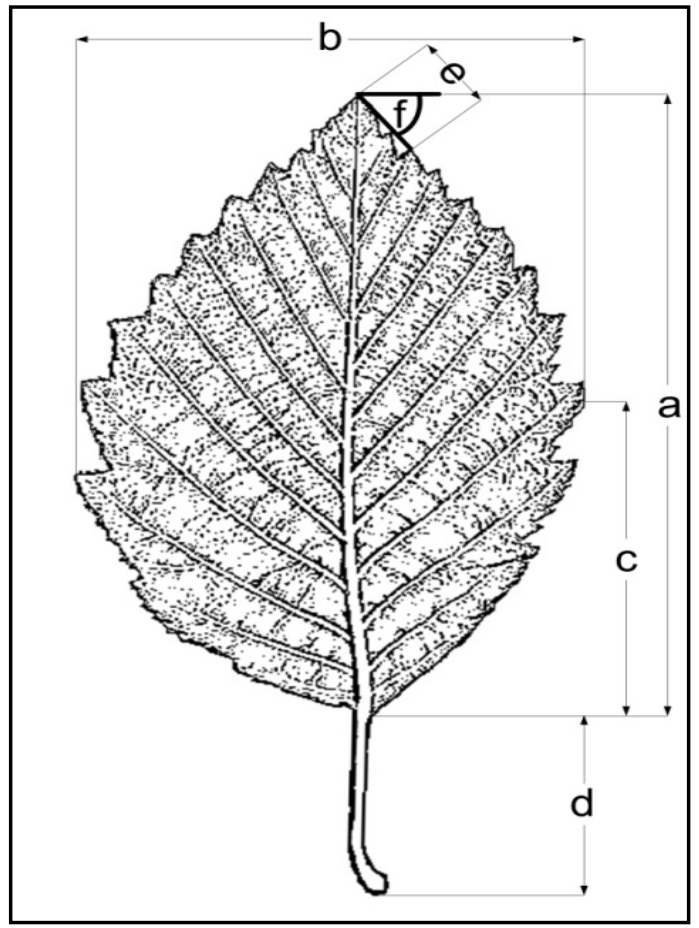

Figure 2. Measured morphometric leaf characters: $a$ - length of a leaf blade, $b$ - width of a leaf blade, $\mathrm{c}$ - distance from the base of a leaf blade to its widest part, $\mathrm{d}$ - length of a leafstalk, e distance from the top of the leaflet to the top of the upper $3^{\text {rd }}$ vein, $f-$ angle from the top of the leaflet to the top of the upper $3^{\text {rd }}$ nerve

Slika 2. Mjereni morfometrijski karakteri lista: $a$-dužina lisne plojke, b - širina lisne plojke, c - udaljenost od baze do najšireg dijela lista, $d$ - dužina peteljke, $e$ - dužina od vrha lista do vrha trećeg nerva, $f$ - ugao od vrha lista do trećeg gornjeg nerva 


\section{RESULTS AND DISCUSSION - Rezultati i diskusija}

Scarcity of data on alders' morphological variability and their geographical distribution in Bosnia and Herzegovina indicates a lack of exploration of this area. Exceptions are data of the leaf variability of black alder within six eastern Bosnian populations (ŠoLJAN 1987), which is insufficient for understanding of the genus Alnus status in this region. According to available literature sources, floristic-vegetation studies of this genus are not conducted from the half of the $20^{\text {th }}$ century, to when be executed taxonomic determination of certain species and recorded several localities (BECK 1907; FUKAREK 1959, 1962).

This paper presents the first results of morphometric analysis of black and grey alder and their hybrids. The obtained data about $A$. x pubescens are of particular importance, since the Bosnian populations are located in their outermost SW areal in the Balkans, where they have never been studied. Mutual cross between black and grey alder, except phenological barriers, presumably are conditioned with some other mechanisms of isolation, since they grow together in a large area in different climatic conditions. It is assumed hybridization is difficult, which was confirmed by specific tests of artificial hybridization (BANAEV 2009). However, PARFENOV (1980) points out the fact that polymorphic species during adaptation have the ability to change its own structure and patterns of biological processes, especially in atypical years when is observed increase in the frequency of hybrids at the ends of the areal and local insular populations.

In Bosnia and Herzegovina, black alder is member of azonal vegetation of wetlands around rivers, streams, ponds and lakes, and its forests, as a smaller fragments, are included in the plant alliance Alnion glutinosae Malc. 1929 (LAKUšıć 1980, OBeRdorfer 1994, VUKelić 2012, TOMić AND RAKONJAC 2013). Also, developmental stages of the vegetation in the higher mountain zones (above $1000 \mathrm{~m}$ ) are observed, mostly in the range of beech forests. On the other hand, grey alder often inhabits around rivers and streams in azonal vegetation of mountain and submontain belts, where comes to the higher altitudes than black alder, especially in the inland area of Bosnia and Herzegovina. Its communities are bound to narrow and intermittent areas along mountain streams (Alnion incanae Pawl. in Pawl. et al. 1928; VuKELIĆ 2012). However, grey alder on the lower limits of its vertical distribution and in the mountain zones is mixed with black alder and form sub-alliance Alnenion glutinosae incanae Oberd. 1953 (RADULOVIĆ AND STEFANOVIĆ 1971, LAKUŠIĆ 1980, OBERDORFER 1994, VUKELIĆ 2012, TOMIĆ AND RAKONJAC 2013).

Determination and isolation of hybrid forms (A. $\times$ pubescens), in relation to the parent species, has been carried out by comparative morphological analysis of seven leaf's quantitative characters of fruiting twigs (Figures 2 and 3). The presence of a small number of hybrids in the analyzed populations confirms the results of similar studies. Thus, BANAEV AND BAŽANT (2007) reported that hybrids are rare in North and Central Europe and western Siberia, noting some increasing in frequency of hybridization in northern boundaries of the species areal. 


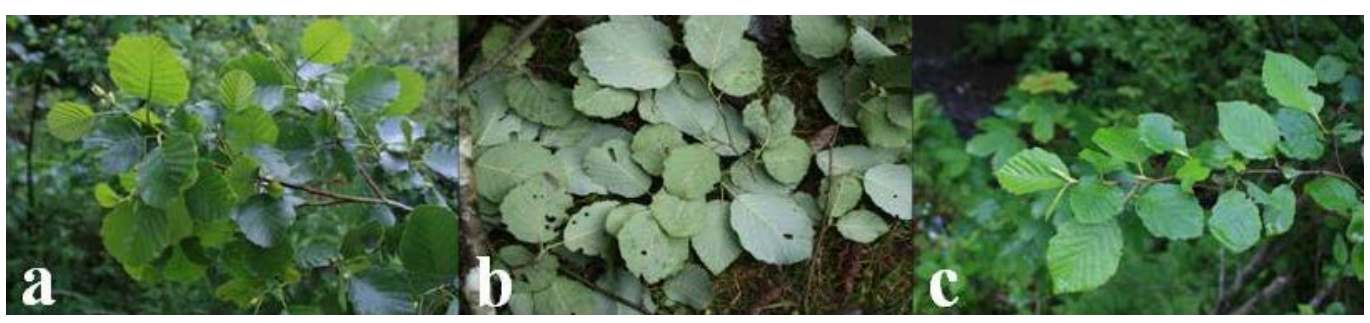

Figure 3. Leaves of a $-A$. glutinosa, $\mathrm{b}-A$. x pubescens, and $\mathrm{c}-A$. incana

Slika 3. Izgled listova $a-$ A. glutinosa, $b-$ A. $x$ pubescens $i c-A$. incana

The results of morphometric measurements of the discriminant characters are presented in Table 2. Data analysis showed that hybrids have more heterogeneous leaves than parental species (Figure 3). Good diagnostic characters showed intermediate values in comparison to the parental species, which are: number of pairs of lateral veins, angle from the top of the leaflet to the top of the upper $3^{\text {rd }}$ nerve, and distance from the top of the leaflet to the top of the upper $3^{\text {rd }}$ vein. The remaining studied leaf characters with its values were closer to grey alder. Obtained results confirm the findings of BANAEV AND BAŽANT (2007 and references therein) that hybrids either hold an intermediate positions between the parental species or are closer to the maternal species (A. incana), in combination with other morphological parameters (surface's hairiness, glandule number on the leaf surface, bark's relief etc.).

Table 2. Morphometric measurements of the discriminant characters

Tabela 2. Morfometrijska mjerenja diskriminativnih karaktera

\begin{tabular}{lccc}
\hline \multicolumn{1}{c}{ Karakteri/characters } & A. glutinosa & A. $\times$ pubescens & A. incana \\
& $\mathrm{R} / \bar{X} \pm \mathrm{sd}$ & $\mathrm{R} / \bar{X} \pm \mathrm{sd}$ & $\mathrm{R} / \bar{X} \pm \mathrm{sd}$ \\
\hline Number of individuals/ Broj jedinki & 24 & 25 & 6 \\
Length of a leaf blade/ Dužina plojke & $4.8-7.4$ & $4.5-7.3$ & $4.7-7.6$ \\
& $6.2 \pm 0.615$ & $6.1 \pm 0.842$ & $6.2 \pm 0.652$ \\
& $3.9-6.3$ & $1.0-5.9$ & $3.0-5.57$ \\
Width of a leaf blade/ Širina plojke & $5.1 \pm 0.506$ & $4.5 \pm 0.868$ & $4.1 \pm 5.547$ \\
& $2.2-4.7$ & $2.4-4.0$ & $2.0-4.2$ \\
Distance from the base of a leaf blade to its widest & $3.6 \pm 0.542$ & $3.1 \pm 0.483$ & $3.0 \pm 0.472$ \\
part/ Udaljenost od baze do najšireg dijela plojke & $0.8-4.0$ & $0.9-2.8$ & $1.0-2.3$ \\
Length of a leafstalk/ Dužina peteljke & $2.3 \pm 0.524$ & $1.6 \pm 0.557$ & $1.5 \pm 0.296$ \\
& $0.9-4.3$ & $0.8-2.5$ & $0.2-1.7$ \\
& $2.6 \pm 0.674$ & $1.3 \pm 0.457$ & $0.8 \pm 0.293$ \\
Distance from the top of the leaflet to the top of the & & & \\
upper 3 ${ }^{\text {rd }}$ vein/ Dužina od vrha plojke do vrha & $1.3-37.2$ & $6.9-62.9$ & $18.8-67.2$ \\
gornjeg 3 nerva $_{\text {Angle from the top of the leaflet to the top of the }}$ & $15.5 \pm 8.355$ & $28.1 \pm 14.511$ & $45.9 \pm 9.871$ \\
upper ${ }^{\text {rd }}$ nerve/ Ugao od vrha plojke do 3 nerva & $6-8(-9)$ & $6-10(-11)$ & $9-13$ \\
Number of pairs of lateral veins/ Broj nerava & $7.3 \pm 0.761$ & $8.9 \pm 1.172$ & $11.1 \pm 1.045$ \\
& & & \\
&
\end{tabular}

Note: $\mathrm{R}$ - range (cm); $\bar{X}$ - average (cm); sd - standard deviation

Napomena: $R$ - raspon (cm); $\bar{X}$ - srednja vrijednost (cm); sd - standardna devijacija 


\section{Data about registered and new localities of hybrid complex of black and grey alder (A. x pubescens) in Bosnia and Herzegovina - Podaci o poznatim $i$ novim nalazištima hibridnog kompleksa crne i sive johe (A. $x$ pubescens) $u$ Bosni i Hercegovini}

The very first findings of hybrid species of black and grey alder in $\mathrm{B} \& \mathrm{H}$ gave BECK (1907), which amends FuKAREK (1962) with two new localities (Figure 1). However, the exact position of the Crna rijeka locality near Sarajevo (FUKAREK 1962) is unclear, since there are two localities near Sarajevo with a given toponym: Crna Rijeka near Trnovo and Crna Rijeka near Kreševo. As documented findings of hybrid complex can be considered an additional two localities recorded in the herbarium of the National Museum in Sarajevo (SARA; Figure 1).

In this study is not confirmed the presence of hybrid individuals in three sympatric alder's populations along the rivers Fojnica, Željeznica near Trnovo (where Crna Rijeka flows into the river Željeznica) and Kreševka near Kreševo, which is not uncommon case. Three new findings of nothospecies $A$. $\times$ pubescens for Flora B\&H are rivers' localities Drinjača near Kladanj, Turbe near Travnik, and Stavnja near Vareš (Figure 1, Table 1). Localities with A. x pubescens in B\&H represent areas of particular interest for the biodiversity protection, source of reproductive materials due to their significant economic values, and live polygons for observations of the evolutionary processes of speciation.

\section{CONCLUSIONS - Zaključci}

Due to the low frequency of observed individuals of $A$. x pubescens, they are vulnerable and require special measures of protection and biodiversity conservation activities of autochthonous gene pool. Since the individuals of $A$. x pubescens can be very interesting both from a number of economically important characteristics in relation to the parental species, and scientific and practical significance for forestry, it is necessary to determine the actual state in all previously published hybrid complexes' findings and expand researches in B\&H in the coming period.

\section{REFERENCES - Literatura}

BALL P.W. (1964): Alnus. In: Tutin T.G. et al. (Eds.), Flora Europaea, University Press, Cambridge, pp. 59.

BANAEV E.V. (1997): Variation in quantitative characters of leaves and female cones in Alnus hirsuta (Betulaceae). Bot. Zh. 82(6): 86-91.

BANAEV E.V., BAŽANT V. (2007): Study of natural hybridization between Alnus incana (L.) Moench. and Alnus glutinosa (L.) Gaertn. Journal of Forest Science 53:66-73.

BANAEV E.V. (2009): On the effect of climate on the morphological structure of Alnus hirsute (Betulaceae). Russian Journal of Ecology 40(1): 18-23. 
Beck G.V.M. (1907): Alnus. In: Beck G.V.M. (ed), Flora Bosne, Hercegovine i Novopazarskog sandžaka, II dio, Zemaljska štamparija, Sarajevo, pp. 101-102.

Bousguet I., Cheliar W.M., LALONDE M. (1989): Allozyme divergence and introgressive hybridization between Alnus crispa and Alnus sinuate (Betulaceae). American Journal of Botany 76: 228-229.

Bousquet J., Cheliak W.M., Wang J., Lalonde M. (1990): Genetic divergence and introgressive hybridization between Alnus sinuata and A. crispa Betulaceae. Plant Systematics and Evolution 170: 107-124.

FUKAREK P. (1959): Pregled dendroflore Bosne i Hercegovine. Narodni šumar, Sarajevo, XIII(5-6): 263-286.

FUKAREK P. (1962): Neka neriješena pitanja u dosadašnjim dendrološkim i dendrogeografskim istraživanjima u Bosni i Hercegovini. Narodni šumar, Sarajevo, XVI (7-9): 357-373.

FurLow J.J. (1979): The systematic of the American species of Alnus (Betulaceae). Rhodora 81: 1-21, 151-248.

HALl R.B., Burgess D. (1990): Evaluation of Alnus species and hybrids. Biomass 22: 21-34.

HYLANDER N. (1957): On cut-leaved and small-leaved forms of Alnus glutinosa and A. incana. Svensk Botanisk Tidskrift 51: 437-453.

LAKUŠıĆ R. (1980): Ekologija biljaka. IGKRO Svjetlost, Sarajevo, pp. 90-95.

OBERDORFER E. (1994): Pflanzen-soziologische Exkursionflora. Verlag Eugen Ulmer, Stuttgart.

PARFENOV V.I. (1980): Dependence of distribution and adaptation of plant species on the area borders. Minsk, Nauka i tekhnika: 205.

PARNELL J. (1994): Variation and hybridisation of Alnus Miller in Ireland. Watsonia 20: $67-70$.

RADULOVIĆ J.V., StEFANOVIĆ V. (1971): Ekološke i azotofiksacione osobine joha. Godišnjak Biološkog instituta Univerziteta u Sarajevu, Svjetlost, Sarajevo, XXIV: 161-178.

SteEle F.L. (1961): Introgression of Alnus serrulata and Alnus rugosa. Rhodora 63: 297-304.

ŠoLJAN D. (1987): Varijabilnost morfoloških karaktera lista crne johe /Alnus glutinosa (L.) Gaertn./. Godišnjak Biološkog instituta Univerziteta u Sarajevu, Sarajevo, 40: 101-115.

The Plant LIST (2013): Version 1.1. Published on the Internet; http://www.theplantlist.org/ (accessed 24.03.2014.).

TOMIĆ Z., RAKONJAC LJ. (2013): Šumske fitocenoze Srbije. Univerzitet Singidunum, Fakultet za primjenjenu ekologiju Futura, Beograd. 
VAnden Heuvel B.D. (2011): Alnus. IN: Kole C. (ed.), Wild crop relatives: genomic and breeding resources, Forest Trees, Springer-Verlag Berlin Heidelberg, DOI 10.1007/978-3-642-21250-5_1.

VUKELIĆ J. (2012): Šumska vegetacija Hrvatske. Šumarski fakultet Sveučilišta u Zagrebu, Državni zavod za zaštitu prirode, Zagreb.

VUKIĆEVIĆ E., JOVANOVIĆ B. (1983): Prilog taksonomskom proučavanju crne i bele jove u okolini Sjenice. Glasnik Šumarskog fakulteta 61, Univerzitet u Beogradu Šumarski fakultet, Beograd: 1-14.

\section{SAŽETAK}

Rod Alnus Mill. (johe) sadrži 20-35 listopadnih vrsta drveća i grmlja od kojih su, prema Flori, u Bosni i Hercegovini prisutne tri autohtone [A. glutinosa (L.) Gaertn crna joha, $A$. incana (L.) Moench - siva joha, A. viridis (Chaix) DC) - zelena joha] te dvije hibridne svojte crne i sive johe, označene kao A. $\times$ tauschiana Callier i $A . \times$ ambigua G. Beck. Međutim, hibridni kompleks crne i sive johe se prema savremenim nomenklaturno-sistematskim poimanjima svrstava unutar nothovrste $A . \times$ pubescens Tausch.. Prirodni interspecijski hibridi kod joha, iako su registrovani, nisu česti. Oni posjeduju mnoge ekonomski važne karakteristike: imaju veću otpornost na sušu u odnosu na roditeljske vrste, heterozis, uspijevaju i na siromašnijim zemljištima, imaju veći kvalitet drveta i bolju otpornost na neke oblike truleži. Zbog navedenog, interspecijaka hibridizacija unutar roda može biti važna strategija za poboljšanje vrsta, a hibridi mogu biti interesantni i kao resursi za selekciju.

Lisni material je sakupljen u šest ekološki heterogenih simpatrijskih populacija, gdje je morfometrijski obrađeno po pet listova sa plodnih grančica, sa ukupno 55 jedinki. Prema modificiranoj metodi BANAEVA I BAŽAnTA (2007), izvršena je analiza varijabilnosti sedam morfoloških svojstava lista: dužina lisne plojke, širina lisne plojke, udaljenost od baze do najšireg dijela lista, dužina peteljke, dužina od vrha lista do vrha trećeg nerva, ugao od vrha lista do vrha trećeg gornjeg nerva i broj nerava.

U istraživanim populacijama je prisutno oko $10 \%$ hibridnih individua. Analiza podataka je pokazala da hibridi imaju heterogenije listove u odnosu na roditeljske vrste, a kao dobri dijagnostički karakteri, koji su iskazali intermedijerne vrijednosti u odnosu na roditeljske vrste, su: broj nerava, ugao od vrha plojke do vrha 3. gornjeg nerva i dužina od vrha plojke do vrha 3. gornjeg nerva. Preostali istraživani karakteri lista svojim vrijednostima su bili bliži sivoj johi. Dobiveni rezultati potvrđuju rezultate drugih studija da hibridi ili zauzimaju središnji položaj između roditeljskih vrsta ili su bliži majčinskoj vrsti (A. incana), a u kombinaciji sa drugim morfološkim parametrima (dlakavost naličja, broj žljezdica na naličju, reljef kore i dr.) su još pouzdaniji u identifikaciji. 
Prve podatke o nalazištima hibridnih svojti crne i sive johe u BiH je daleke 1907. godine dao Beck, što je 1962. godine dopunio Fukarek sa dva nova nalazišta. U ovoj studiji nije potvrđeno prisustvo hibridnih jedinki u tri simpatrijske populacije joha uz rijeke Fojnica, Željeznica kod Trnova (u koju se ulijeva Crna rijeka) i Kreševka kod Kreševa, što nije rijedak slučaj. Tri nova nalazišta nothovrste $A$. × pubescens za Floru BiH su lokaliteti rijeka Drinjača kod Kladnja, Turbe kod Travnika i Stavnja kod Vareša. Bosanskohercegovačke individue A. x pubescens su nedovoljno istražene i od posebnog su značaja, jer se nalaze na krajnjem JZ arealu Balkana, gdje do danas nisu bile istraživane. Lokaliteti sa $A$. x pubescens predstavljaju prostore od posebnog interesa za zaštitu biodiverziteta, izvor reproduktivnog materijala za njihovu produkciju zbog značajnih ekonomskih vrijednosti te žive poligone za praćenje odvijanja evolucionih procesa specijacije, pa je u narednom periodu neophodno utvrditi stvarno stanje na svim prethodno publikovanim nalazištima hibridnog kompleksa i proširiti istraživanja na području $\mathrm{BiH}$. 